\title{
POÉTICAS DA MODERNIDADE
}

O número que finalmente chega ao leitor reúne artigos que, de um modo ou de outro, vão se ater a um dos temas fundamentais da obra de Walter Benjamin: a Modernidade, suas contradições e possibilidades, as interrupções violentas que promovia e os novos horizontes possíveis que descortinava. Em leituras que vão desde o modernismo europeu de Virginia Woolf, passando pelo cinema do italiano Pier Paolo Pasolini (um dos críticos mais agudos da modernidade) até a obra dos romancistas brasileiros Graciliano Ramos e Milton Hatoum - leitores atentos, cada um deles em seu próprio tempo, dos efeitos perversos do processo de modernização social e econômica do país -, o conjunto de textos que se oferece ao público tem em Benjamin um interlocutor preciso, seja para descrever a maquinaria estética ou social da vida moderna (como se vai fazer, por exemplo, a partir da leitura da obra do poeta francês Charles Baudelaire), seja para especular em torno de novas formas e diferentes possibilidades formais trazidas à tona, para o centro do campo literário, pelas reflexões benjaminianas sobre a coleção, o colecionismo e os sistemas de classificação do mundo e do conhecimento.

Sempre parcial, uma reunião de artigos redigidos para pensar, a partir do influxo de Walter Benjamin, a questão do Moderno, tem a vantagem de repropor, a partir de distintos e às vezes inesperados objetos, a atualidade e a urgência da reflexão benjaminiana, de modo especial a crítica que vai fazer à teoria do progresso, tema tão intimamente relacionado ao universo da Modernidade.

Os organizadores 